\title{
Clinical supervision and preceptorship/tutorship: contributions to the Supervised Curricular Internship in Nursing Education
}

\author{
Supervisão Clínica e preceptoria/tutoria - contribuições para o Estágio Curricular Supervisionado \\ Supervisión clínica y preceptoría/tutoría: contribuciones a la Práctica Curricular Supervisada en la educación en Enfermería
}

\section{Larissa Sapucaia Ferreira Esteves' \\ ORCID: 0000-0003-3489-2599 \\ Isabel Cristina Kowal OIm Cunha' \\ ORCID: 0000-0001-6374-5665 \\ Elena Bohomol' \\ ORCID: 0000-0002-7196-0266 \\ Margarida Reis Santos" \\ ORCID: 0000-0002-7948-9317}

\section{' Universidade Federal de São Paulo. São Paulo, São Paulo, Brazil. "Escola Superior de Enfermagem do Porto. Porto, Portugal. \\ How to cite this article: \\ Esteves LSF, Cunha ICKO, Bohomol E, Santos MR. \\ Clinical supervision and preceptorship/tutorship: contributions to the Supervised Curricular Internship in Nursing Education. Rev Bras Enferm. 2019;72(6):1730-5. \\ doi: http://dx.doi.org/10.1590/0034-7167-2018-0785 \\ Corresponding Author: \\ Larissa Sapucaia Ferreira Esteves \\ E-mail: larissasapucaiaesteves@gmail.com

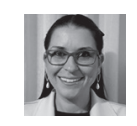

Submission: 10-29-2018 Approval: 03-15-2019

\section{ABSTRACT}

Objective: To reflect on the contributions of the clinical supervision and preceptorship/ tutorship as means to approach and engage nurses of healthcare services in activities related to the Supervised Curricular Internship, discussing conceptual, theoretical, and practical approaches for higher education in nursing. Method: This is a reflection based on the discursive formulation concerning clinical supervision and preceptorship/ tutorship. Results: Clinical supervision has been widely used by international healthcare institutions to qualify the work processes of nurses, supporting their self-development. Currently, is has been supporting the work of nurses who are preceptors/tutors and monitors students on clinical internships. Final considerations: The clinical supervision of nursing students features a robust and effective strategy for the development of interns and for the completion of the teaching-service integration.

Descriptors: Teaching; Internships; Preceptorship; Nursing Education; Higher Education.

\section{RESUMO}

Objetivo: Refletir sobre as contribuições da supervisão clínica e da preceptoria/tutoria como meios para a aproximação e envolvimento dos enfermeiros dos serviços de saúde nas atividades de Estágio Curricular Supervisionado, discutindo enfoques conceituais, teóricos e práticos para o ensino superior em enfermagem. Método: Trata-se de estudo reflexivo fundamentado na formulação discursiva acerca da supervisão clínica e da preceptoria/tutoria. Resultados: a supervisão clínica tem sido amplamente utilizada pelas instituições de saúde internacionais para qualificar os processos de trabalho dos enfermeiros, apoiando seu autodesenvolvimento. Atualmente tem fundamentado a atuação do enfermeiro preceptor/tutor que acompanha estudantes na realização de estágios clínicos. Considerações finais: A supervisão clínica de estudantes de enfermagem se apresenta como estratégia robusta e eficaz para o desenvolvimento do estudante em estágio e para a efetivação da integração ensino-serviço.

Descritores: Ensino; Estágios; Preceptoria; Educação em Enfermagem; Ensino Superior.

\section{RESUMEN}

Objetivo: Reflexionar sobre las contribuciones de la supervisión clínica y de preceptoría/ tutoría como forma de acercamiento y participación de los enfermeros de los servicios de salud en las actividades de Práctica Curricular Supervisada, discutiendo los enfoques conceptuales, teóricos y prácticos para la enseñanza superior en enfermería. Método: Se trata de un estudio reflexivo a partir de la formulación discursiva acerca de la supervisión clínica y de la preceptoría/tutoría. Resultados: la supervisión clínica es ampliamente utilizada por las instituciones de salud internacionales para calificar los procesos de trabajo de los enfermeros, apoyando su autodesarrollo. Actualmente motiva la actuación del enfermero preceptor/tutor el que acompaña a los estudiantes en las prácticas clínicas. Consideraciones finales: La supervisión clínica de estudiantes de enfermería se caracteriza como una estrategia robusta y eficaz para el desarrollo del estudiante en las prácticas y para la efectividad de la integración enseñanza-servicio. Descriptores: Enseñanza; Prácticas; Preceptoría; Educación en Enfermería; Educación Superior. 


\section{INTRODUCTION}

According to the National Curriculum Guidelines (Diretrizes Curriculares Nacionais - DCNs) for undergraduate programs in nursing, the vocational training of nurses should be carried out aiming at developing skills to work in the complex Brazilian Healthcare System, ensuring completeness in the care, problemsolving within the individual and collective scopes, management of healthcare processes at the local level, and the ability to work collectively. To do so, the science of the profession should be developed by undergraduate programs through theoretical lectures, practical classes in laboratories, practical classes in healthcare services, and Supervised Curricular Internships (Estágio Curricular Supervisionado - ECS), in which students and professionals engage and strengthen their knowledge (knowing, doing, being, and coexisting) required for the professional practice of the nurse ${ }^{(1)}$.

Although since 2001 the DCNs point to how undergraduate programs in nursing must organize the educational process in Brazil, there are doubts and difficulties in the implementation of ECS as a final step of the training. ECS should have at least $20 \%$ of the total workload of the program and must be carried out in the last two semesters, preceded by theory, laboratory practice, clinical practice, being pedagogically organized by the teaching staff and tutored by nurses of healthcare services, where the activities are carried out. The absence of such education model disobliges the process of actionreflection-action required for a critical and reflective training ${ }^{(1-2)}$.

Authors of an integrative literature review, recently published, concluded that ECS has a central role in the professional training of nurses, because it enables the insertion of students in the reality of health care, as it actually is, without manipulation or adjustments to the achievement of teaching-learning processes. Moreover, they present evidence that highlight the importance of the active participation of nurses in supervision activities, since they represent the profession materialized for the student, in addition to being one of the key actors for the implementation of educational practices in a real working scenario ${ }^{(2)}$.

One of the difficulties for the implementation of ECS is the lack of clarity regarding the role of nurses in healthcare services, difficulties in expanding and adjusting the provision of fields for clinical practice and ECS due to increase in higher education institutions without broadening the provision of healthcare services. These barriers undermine the conditions to welcome students, tutors, and teachers for the development of internship activities ${ }^{(2)}$.

Although the scenarios for conducting ECS activities are diversified, and active methodologies are being implemented, the active participation of nurses working in healthcare services in the supervision of seniors is not yet a consensus among the different schools of nursing. Therefore, students are monitored during their entire training by teachers, which, often, are far from the working reality of nurses ${ }^{(2)}$. Indeed, the higher education institution is responsible for the development of didactic-pedagogical activities in healthcare services ${ }^{(1)}$; however, the lack of participation of nurses in the planning and completion of such training compromises the relationship between teaching and service. Thus, the vocational training would be dependent on the professional practice and, consequently, in the medium term, the efficiency and quality of health care provided to the population would be compromised ${ }^{(2)}$.
In this reflection we exclusively focus on the role of healthcare professionals in the implementation of the ECS activities, considering that the Brazilian legislation provides for nursing as an important and required professional training ${ }^{(1)}$, since nurses are the professionals who mobilize skills that are expected to be developed in students. To do so, our background will be the concepts of Clinical Supervision (CS) in nursing education, considering the scarcity of studies in Brazil on this perspective ${ }^{(3)}$, and preceptorship/tutorship, which are adopted in undergraduate programs in nursing in several countries for some time.

\section{OBJECTIVE}

To reflect on the contributions of the clinical supervision and preceptorship/tutorship as means to approach and engage nurses of healthcare services in activities related to the Supervised Curricular Internship, discussing conceptual, theoretical, and practical approaches for higher education in nursing.

\section{METHOD}

This is a reflection based on discursive formulation regarding CS and preceptorship/tutorship, developed by concepts and theoretical and practical perspectives, based on the experiences of undergraduate programs in nursing in other countries, described in current references.

The text is organized as follows: introduction; clinical supervision and preceptorship/tutorship: theoretical and practical perspectives; international experiences on clinical supervision and preceptorship/tutorship in undergraduate programs in nursing; and ideas for undergraduate programs in nursing in Brazil: the Supervised Curricular Internship and Clinical Supervision.

\section{REFLECTION}

\section{Clinical supervision and preceptorship/tutorship: theoreti- cal and practical perspectives}

The term "supervision," in Brazil, is closely related to managerial activities of nurses, having little prominence to education. Currently, conceived as a way to carry out broad clinical practice aiming at ensuring networking, it is sustained in understanding a management tool that can enable better planning, implementation, and evaluation of comprehensive health care to the users, supporting teamwork in nursing ${ }^{(3)}$. Preceptorship and tutorship are concepts linked to healthcare professionals who are responsible for the teaching-assistance supervision, with theoretical bases supporting the practice by means of mediation and articulation of theoretical and practical knowledge of professionals who have recently graduated from school and are currently attending residency programs ${ }^{(4)}$.

Conceived as a process to increase the quality of professional practice, the CS is defined as a formal process for supporting work and learning that helps professionals developing knowledge and skills, ability to take responsibility for their actions, and improving the protection and safety of patients in complex situations. CS also aims to develop the restorative function aimed to assist professionals in overcoming labor-related stress ${ }^{(4-5)}$. This methodology has 
been integrated to the education processes of students because it is a systematic and professional process for developing skills, including guidelines developed in the United Kingdom, Canada, and Australia. The vocational training is developed with the support of self-assessment, supervision, and reflection on work processes, aiming at the implementation of reflective practices and, consequently, personal and professional development ${ }^{(4-5)}$.

Although related, the terms "CS,"'mentorship,"'"preceptorship," and "tutorship" have distinct assumptions regarding education in nursing. CS focuses on the nurses' development of clinical practice reflection, guidance, and professional support ${ }^{(4-5)}$, and it has been adopted by institutions of higher education within the European Union to sustain and consolidate the development of clinical education, in which students are monitored by nurses of the healthcare services in its internship activities. The term "mentorship" is related to the guidance from an expert professional to a less experienced, new graduate, or newly hired by healthcare services. "Preceptorship" and "tutorship" are directed to the monitoring and guidance of nursing students, although it may vary according to the cultural contexts in which they are employed ${ }^{(4)}$.

The systematic monitoring of nursing students on the part of the service is based on the CS concepts, because it aims to overcome the historicity of ritualistic learning, based on the accomplishment of tasks, in favor of meaningful learning, focusing on the development of clinical skills, supported by the logic of reflection on action and about the action, seeking to develop the ability to solve complex problems ${ }^{(6)}$. Its implementation occurs by the preceptorship monitoring logic. Healthcare nurses, who work as preceptors/tutors of students, know specific features of the work context and how to integrate them into the interdisciplinary nursing team. However, students and preceptor/tutor nurses must know in depth the requirements and objectives of the internship in order to exercise supervision, providing mechanisms in such a way to achieve constructive, educational, and improvable evaluation processes ${ }^{(7)}$.

The educational process of nursing students undertaking clinical internship (EU nomenclature), or ECS (the internship equivalent in Brazil), is deemed a difficult and complex phase. We must ensure the socialization of future nurses in the profession, the fusion of theoretical and practical knowledge acquired throughout the program, which will be materialized in the awareness of an autonomous and responsible work, supported by critical thinking, resulting in the development of skills for better decision-making. Therefore, in CS the preceptor/tutor takes on the role of developing activities planned together with the professor, in such a way to supervise, teach, instruct, train, advise, and evaluate, supporting the student to ensure the completeness of the future generalist nurse. Preceptor/tutor nurses favor the transition between being a nursing student and being a professional, decreasing the reality shock experienced by new graduates ${ }^{(2,4-6)}$.

It is believed that education is an ongoing process of personal ownership of knowledge, within contexts that favor interaction, leading to the development of professional skills, since these involve knowing what to do in a particular situation. Preceptors/ tutors make the moments of observation and intervention within work contexts tangible, and in this training environment students are expected to develop behaviors and self-regulation processes, and to integrate, mobilize, and encourage knowledge acquired in the theoretical and practical learning, through contact with different situations experienced in the real world of the profession ${ }^{(6)}$.

\section{International experiences concerning clinical supervision and preceptorship/tutorship in undergraduate programs in nursing}

The European Parliament Directive, enacted in 2005, guided the homogenization of academic training in order to ensure the abolition of obstacles to the free movement of persons and services between Member States. Hence, a uniform system of undergraduate programs and equalization between university degrees was developed, encouraging student mobility. Education of nurses began to be developed through, at least, 4,600 hours, and $50 \%$ of the workload must be directed to clinical education, since education for vocational training requires direct contact with users of healthcare systems ${ }^{(8)}$.

Since then, in Portugal, nurses have been summoned to actively participate in the training of nursing students as tutors, performing supervision activities. In this process, they receive the didacticpedagogic monitoring and support from professors of the higher education institution, which is responsible for such training ${ }^{(4)}$. In Austria, CS is divided between nurses who are teachers of educational institutions and nurses who work in healthcare services. Teachers discuss the planning of nursing care, difficulties in the implementation of interventions, and give feedback to students about their performance after discussion with the nurse tutor, who performs CS in the day-to-day work, articulated with the proposal for a previously planned education ${ }^{(8)}$. In Slovakia, the clinical learning environment is subject of studies because it is configured as a paramount part in undergraduate programs in nursing comprising general skills, and pedagogical approaches are used for guiding the students. Supervision models and the workload for the clinical education were identified as predictive factors of students' learning ${ }^{(7)}$.

There are several CS models sufficiently well developed, considered comprehensive, and theories widely tested throughout Europe. The core of those used in the training of nursing students consists in learning through self-criticism, self-supervision, and reflection about work processes. The restorative role of CS is associated with the support for personal well-being and management of the stress related to the leaning environment, future workplace ${ }^{(5)}$.

It is consensus among studies ${ }^{(4-5,7-9)}$ that the education of nurses to perform the role of preceptor/tutor is essential for the success of teaching-learning processes. Among important content areas for the professional training of the service we highlight teaching-learning strategies, communication and supervision, resolution of conflicts, objectives and goals expected regarding the program according to which students will be supervised, and learning evaluation. Adequate training for the development of the role of tutor allows nurses to adjust their practices in such a way to become better models for students ${ }^{(8)}$.

Ideas for undergraduate programs in nursing in Brazil: the

The training of nurses in Brazil has been the subject of debate among higher education institutions, representative bodies of the 
class, and the Government for over 20 years, generating numerous policies and resolutions. Several causes of the education process have been elucidated over the years; however, others remain unsolved, and some dare say they seem to be veiled for several reasons. Which is the case with the development of ECS in healthcare services.

Legislation on education is clear regarding the workload that must be exclusively directed to the development of ECS, the need of students' preparation to attend the ECS activities, and the importance of the approach between vocational training services. Since nursing skills required to provide health care towards complex cases are mobilized in the professional practice, with safety, quality, and responsibility, which compose the national healthcare system, the participation of the professional who works in healthcare services is paramount at this period of the academic training. Although the context of nursing work in Brazil is different from work processes developed in other countries, this fact does not prevent us from reflecting on and debating about models for monitoring students in clinical internships already consolidated in other countries.

The ECS, besides being an important component of the syllabus, consists in an approximation and articulation between schools and healthcare units. At this point, students are expected to use knowledge, skills, and professional behaviors learned by them, enhancing their skills, which are strongly influenced by the work processes of the healthcare institutions ${ }^{(2)}$. Therefore, it makes no sense for the vocational training to be exclusively monitored by professors and actors linked to educational processes without the effective participation of professionals who actually mobilize their knowledge for solving complex health problems and management issues that daily occur in healthcare services ${ }^{(6)}$.

Ensuring this training component, with the required quality, is only possible based on solid partnerships between educational institutions, healthcare organizations, and nurses who participate in the supervision processes of nursing students in ECS. In such a way there is articulation between the school and the service, two conditions are essential: the open capacity of, constructively, questioning theories and practices; and the existence of permanently former communication channels. Ensuring socialization between future nurses and the profession is, undoubtedly, the responsibility of the school, and it can only be achieved in partnership with healthcare services ${ }^{(4,6)}$.

Authors of a study developed in Austria showed that the support given by preceptor/tutor nurses, in partnership with professors in clinical education contexts, resulted in positive effects on students who have improved their performance concerning selfawareness, expectation of self-efficacy, and learning success. In addition, the teaching component embedded in the discussions with healthcare services had a positive impact on teamwork ${ }^{(8)}$.

In healthcare services there is a clinical learning environment, which is defined as a multidimensional entity, an interactive network of different aspects within the healthcare unit of work, influencing students' opportunities to learning outcomes. Learning environments comprise four important features for clinical learning: environment and physical space; psychosocial and interaction factors; effectiveness of the preceptor/tutor's teaching; involvement of students and the educational institution; and organizational culture(7).
CS is an efficient strategy in the monitoring of nursing students by preceptor/tutor nurse ${ }^{(3-8)}$. In a systematic review of the literature on the subject, the CS model more used is the Proctor ${ }^{(4)}$, since it has greater relevance for the quality of nursing care. This model proposes three paramount components for its implementation. The Normative refers to the responsibility and professional satisfaction, including actions intended to increase safety, quality, and management. The Formative is focused on the development and enrichment of personal and professional knowledge and skills. And the Restorative is directed to emotional responses and to the necessary support concerning components and responsibilities upon the requirements of the context ${ }^{(4)}$.

For implementing CS in ECS, schools and healthcare services must adhere to an agreement of joint co-responsibility both in relation to the education of professionals and to the training of preceptor nurses, requiring energy expenditure of both parties. With this strategy not only teaching is benefited, but also healthcare institutions with nurses focused on the needs of users, ensuring safety in the provision of care, and quality of the work ${ }^{(9-10)}$.

For the implementation of CS of nursing students, school and healthcare services will need, initially, to select the nurses that have to compose the board of preceptors/tutors. Nurses with longer periods of professional experience and working in the institution, who know the social processes of the workplace and have relational skills are the most suitable. In addition to the technical question of selection, coordination with the involved personnel is necessary because being a preceptor should evoke personal and professional satisfaction, creating an environment in which nurses and students can grow and thrive ${ }^{(10)}$.

It is known that the best experiences with CS come from universities that promote training for preceptors/tutors and where there is support from the healthcare institution for an approximation with the school ${ }^{(7,10)}$. To welcome student in ECS, nurses must be properly trained regarding their duties as preceptor/tutor, recognizing the education trajectory proposed by the school, teaching goals, ways to develop critical thinking that can support students' decision-making, which is expected of them, and how to assess learning needs and developed skills. The preceptorship experience increases the opportunity for new learning experiences, improves the performance of the assistive skills, and increases the ability to manage the provision of health care for a group of users ${ }^{(10)}$. Implementing the CS model of nursing students in ECS enables to systematically evaluate features of the clinical learning environment.

Measuring the effectiveness of training through tested and validated instruments allows the systematic analysis of deployed strategies, in addition to providing a background with other training institutions. Several instruments enable measuring the dimensions of the educational and social role of the clinical practice and the impact of different supervision models on the perception of interns. One of the most used tools to measure students' perceptions in European countries is the Clinical Learning Environment, Supervision and Nurse Teacher $(\mathrm{CLES}+\mathrm{T})^{(7)}$.

In Brazil, we perceive an educational practice disconnected from the work practice of nurses, since schools face several obstacles, both imposed by legislation and by healthcare institutions, concerning the participation of nurses in education services preventing 
students from actively participating in the production of the work in health. Deploying measures which may reduce the existing dichotomy between theory and practice is deemed priority, throughout the academic education and between the discourse and the concrete action observed in the reality of healthcare services. To do so, schools and healthcare services have the challenge of educating future professionals to obtain skills and knowledge essential for the reflection and definition of priorities, to face ambiguous situations, and to tolerate uncertainties that are part of the work processes. We cannot have a quality education without the legitimate partnership with healthcare services. There is no way of ensuring health completely safe, networking-type, and innovative without co-responsibility of education.

\section{Limitations}

The central idea of the study is not depleting concepts, theories, methods, and possibilities when it comes to CS and preceptorship/tutorship, but reflecting on the education in nursing in Brazil issue, more specifically in relation to the development of ECS in undergraduate programs. Moreover, we aimed to point guidelines that could support the debate among health and education institutions.

\section{Contributions to the field of nursing, health, or public policies}

In this reflection we presented a methodology of professional support regarding the monitoring of students undergoing Supervised Curricular Internship by nurses of healthcare services. We intend to contribute both to formative processes, and to healthcare institutions and fields of internship, since it will help in guiding and in the organized and systematized insertion of nurses of the healthcare services into monitoring seniors on their last training period. This theme is deemed emerging, because the teachingservice approach is essential for the training of professionals with skills to work in the complex Brazilian healthcare system.

\section{FINAL CONSIDERATIONS}

The Supervised Curricular Internship has been subject of debates and resolutions regarding its achievement in healthcare institutions, the education-service articulation, and the participation of professional nurses of the institutions in organization, planning of activities, and development of the professional future. The education of nurses in Brazil provides for the development of internship activities in healthcare services mediated by nurses. Concepts that comprise the processes of Clinical Supervision and preceptorship/tutorship are robust methods for the monitoring and development of skills of students in clinical training in other countries. Such concepts do not overlap teaching methodologies employed by Brazilian nursing schools concerning Supervised Curricular Internships, since it aims at organizing and systematizing the participation of professional nurses who welcome students in healthcare services. However, there is a need to broaden discussions on the proposal, to deepen the knowledge, and to develop research with both teaching and healthcare institutions that use the method of Clinical Supervision and preceptorship/ tutorship of interns.

\section{FUNDING}

Research funded by the Coordination for the Improvement of Higher Education Personnel Foundation (CAPES).

\section{REFERENCES}

1. Ministério da Educação (BR). Conselho Nacional de Educação (CNE). Câmara de Educação Superior (CES). Resolução CNE/CES nº. 3, de 7 de novembro de 2001. Institui Diretrizes Curriculares Nacionais do Curso de Graduação em Enfermagem [Internet]. Brasília; 2001 [cited 2018 Sep 14]. Available from: http://www.cofen.gov.br/wp-content/uploads/2012/03/resolucao_CNE_CES_3_2001Diretrizes_Nacionais_Curso_ Graduacao_Enfermagem.pdf

2. Esteves LSF, Cunha ICKO, Bohomol E, Negri EC. Supervised internship in undergraduate education in nursing: integrative review. Rev Bras Enferm [Internet]. 2018;71(Suppl 4):1740-50. [Thematic issue: Education and teaching in Nursing] doi: 10.1590/0034-7167-2017-0340

3. Chaves LDP, Mininel VA, Silva JAM, Alves LR, Silva MF, Camelo SHH. Nursing supervision for care comprehensiveness. Rev Bras Enferm [Internet]. 2017;70(5):1106-11. [Thematic Edition "Good Practices and fundamentals of Nursing work in the construction of a democratic society"] doi: 10.1590/0034-7167-2016-0491

4. Silva R, Pires R, Vilela C. Supervisão de estudantes de Enfermagem em ensino clínico: revisão sistemática da literatura. Rev Enf Ref [Internet]. 2011 [cited 2018 Sep 14];serllI(3):113-122. Available from: http://www.scielo.mec.pt/pdf/ref/vserllln3/serllln3a12.pdf

5. Koivu A, Saarinen PI, Hyrkas K. Who benefits from clinical supervision and how? The association between clinical supervision and the workrelated well-being of female hospital nurses. J Clin Nurs. 2012;21(17-18):2567-78. doi: 10.1111/j.1365-2702.2011.04041.x

6. Alarcão I, Rua M. Interdisciplinaridade, estágios clínicos e desenvolvimento de competências. Texto Contexto Enferm. $2005 ; 14(3): 373-82$. doi: 10.1590/S0104-07072005000300008

7. Gurková E, Žiaková K. Evaluation of the clinical learning experience of nursing students: a cross-sectional descriptive study. Int J Nurs Educ Scholarsh. 2018;15(1). doi: 10.1515/ijnes-2017-0053

8. Mueller G, Mylonas D, Schumacher P. Quality assurance of the clinical learning environment in Austria: Construct validity of the Clinical Learning Environment, Supervision and Nurse Teacher Scale (CLES+T scale). Nurse Educ Today. 2018;66:158-65. doi: 10.1016/j. nedt.2018.04.022 
9. Ward A, McComb S. Precepting: a literature review. J Prof Nurs. 2017;33(5):314-25. doi: 10.1016/j.profnurs.2017.07.007

10. Rogan E. Preparation of nurses who precept baccalaureate nursing students: a descriptive study. J Contin Educ Nurs. 2009;40(12):565-70. doi: 10.3928/00220124-20091119-06 